\title{
Can Social Performance Improve Financial Performance and Increase Customers' Trust?
}

\author{
Hasan Mukhibad ${ }^{1}$, Indah Anisykurlillah ${ }^{1}$, Ahmad Nurkhin $^{1} \&$ Prabowo Yudo Jayanto ${ }^{1}$ \\ ${ }^{1}$ Faculty of Economics, Universitas Negeri Semarang, Central Java, Indonesia \\ Correspondence: Hasan Mukhibad, Faculty of Economics UNNES, Sekaran Campus, Gunungpati, Semarang, \\ Central Java, Indonesia. Tel: 62-8229-9004-434.
}

Received: March 4, 2019

Accepted: May 27, 2019

Online Published: June 19, 2019

doi:10.5430/ijfr.v10n4p37

URL: https://doi.org/10.5430/ijfr.v10n4p37

\begin{abstract}
Social concern is strongly emphasized in Islam. There are the concepts of khalifah fil ard, hablum min nass, tawazun in Islam which demonstrate the Islamic approach to concern for social issues. The purpose of this study is to obtain evidence pertaining to whether social concern in Islamic banks has an impact on improving their performance and the trust of customers. The research sample is 11 Islamic commercial banks in Indonesia. The observation period was from 2009 to 2017. The results of this study show that social activities carried out by banks in the form of qardh financing, and the distribution of qardh al-hassan and zakah funds, were able to increase customer trust in the banks. This increase in trust is evidenced by the positive influence of channeling social funds on increasing debt and temporary syirkah funds. However, the distribution of social funds does not have a positive impact on the amount of funding channeled by banks. As a result, the bank's income from the disbursement of finance cannot increase, and the impact of the bank's profitability does not increase. So, it has been proven empirically that the distribution of social funds does not have a positive impact on the amount of financing and profitability as measured by ROA and ROE.
\end{abstract}

Keywords: social performance, qard, zakah, qardh al-hassan financing

\section{Introduction}

Islamic banks are banks that use sharia law or principles in their operations. One of the sharia laws pertains to concern for the environment. The Qur'an, as a source of Islamic law, has more verses on the environment than verses about commandments and sacraments (R. Rizk, 2014). Another concept in Islam that emphasizes environmental concern is the concept of khalifah fil ard, which means that all humans have duties and responsibilities (in gaining the trust of God) in terms of preserving the planet Earth (R. Rizk, 2014). In line with the opinion of (R. Rizk, 2014), Jusoh, Ibrahim, \& Napiah (2015) have shown that social responsibility is part of fundamental Islamic teachings based on the concept of khalifah.

According to Dien (1997), Islamic teachings that emphasize concern for the preservation of nature are based on (1) the environment being God's creation; (2) the concern is a form of protection of God's creatures who praise and pray to Him; (3) the notion that the environment is a divine creation that deserves to be protected; (4) Islam is built based on the concept of goodness; (5) human relations in Islam must be based on the concept of justice, and goodness, and not on material or economic benefits. Thus, Islam strongly emphasizes that its adherents must be righteous in their social concern, and also in terms of social management, environment, and ethics, both indivually and organizationally (Platonova, Asutay, Dixon, \& Mohammad, 2016).

One way that the concern of an Islamic bank for its social environment can be measured is through the social disclosure in its annual report which is called the Islamic Social Responsibility (ISR) disclosure. ISR disclosure has been used by Sugianto \& Harapan (2017), Sofyani, Ulum, Syam, \& Wahjuni (2012), Santoso \& Dhiyaul-haq (2017), Pratama (2018), Assegaf et al., (2012), Asriati, Ulfah, \& Setyorini, (2016), and Sari (2018), who find that what is disclosed in the ISRs of Islamic banks in Indonesia is still low (Mukhibad, 2018).

Another indicator in measuring the concern of Islamic banks towards their social and natural environments is to use financial ratios. Fitrijanti \& Alamanda (2013); Hameed, et al. (2004) and Mukhibad, Nurkhin, \& Khafid (2016) use the performance of zakah (religious donations) and qardh al-hassan funds as indicators of the social performance of Islamic banks. In addition, Falikhatun, Assegaff, \& Hasim (2016); Sa'ad \& Ibrahim (2015) show that qardh 
al-hassan financing is social financing. Thus, in addition to the performance of zakah and qardh al-hassan funds and the ratio of qardh financing (benevolent loans) can be used as a measure of the bank's social performance.

Data published by bank Indonesia show that the ratio of qardh financing as a measure of the social performance of Islamic banks in Indonesia remains small, with an average value of $1.80 \%$. This fact is in line with the statement of Agus Martowardojo (Governor of Bank Indonesia) which contended that Islamic banks in Indonesia are still weak in channeling social financing (Hamidi, 2016).

Regarding research on social performance, many researchers have demonstrated empirically what the factors are that influence social performance in Islamic banks. In this study, the researchers have developed social performance as an independent variable that has an influence on improving bank financial performance. Research on the effect of CSR on financial performance has been discussed by many researchers, but the results still do not provide clarity as to whether CSR increases the economic performance (Francis, Harper, \& Kumar, 2016). Researchers have noted that CSR enables companies to differentiate themselves in the marketplace for their products (Francis, Harper, \& Kumar, 2016) while increasing the number of customers (Lev, Petrovits, \& Radhakrishnan, 2012; Servaes \& Tamayo, 2013; Mukhibad, 2018).

The novelty of this study is that the test relates to the impact of social performance on all stakeholders and not only the shareholders of the Islamic banks which are the object of study. The reason for this is that existing research has rarely discussed the effect of CSR on bank performance (Francis et al., 2016), especially Islamic banks. Another reason is that banks take large risks in their operations (Francis et al., 2016), and this is even more the case with Islamic banks (Lassoued, 2018; Boumediene, 2010; Ahmed \& Tariqullah, 2007). The risks faced by Islamic banks concern credit risk, interest-rate risk, and liquidity risk (How, Karim, \& Verhoeven, 2005). Ahmed \& Tariqullah (2007) which shows that the risks faced by Islamic banks are more diverse than conventional banks.

Research that demonstrates empirically the influence of social performance on the profitability of Islamic banks has been conducted by Mukhibad (2018); Platonova et al. (2016); Mallin, Farag, \& Ow-yong (2014) who find that social performance affects the performance in the subsequent year. The difference between this research and previous research by Mukhibad (2018); Platonova et al. (2016); Mallin et al. (2014) is the measurement of social performance uses financial ratios, not based on the extent of both CSR or ISR disclosure. The measurement of social performance in this study uses qardh financing ratios, and the performance of zakah and qardh al-hassan funds. The performance of zakah and qardh al-hassan uses the amount of zakah funds and qardh al-hassan funds distributed. This is because the expenditure on zakah and qardh al-hassan is from funds collected and channeled in the form of social activities of Islamic bank.

Islamic banks are banks whose operations are based on sharia principles. Law No.21 of 2008, pertaining to Sharia Banks, limits sharia principles used by Islamic banks to the fatwa (rulings) of the National Sharia Council (DSN). That is to say, compliance with Islamic banks in terms of sharia principles is limited to the use of covenants issued by the National Sharia Council (Dewan Syariah Nasional).

However, many parties consider that compliance with sharia principles also involves social concerns and environmental concerns. Humans are tasked with becoming caliphs on Earth (Beekun \& Badawi, 2005; R. R. Rizk, 2014). God created the Earth and humans have the task of managing it and they will be held to account by God. In the management concept, humans must maintain and care for the Earth, so that it can continue to be used in accordance with the purpose of its creation.

The Qur'an, as a source of Islamic law, strongly emphasizes that its adherents have to be concerned for the environment. Analysis by Helfaya, Kotb, \& Hanafi (2018) has identified 675 verses in 84 chapters throughout 30 parts of the Qur'an that have environmental content related to the core components of the natural world, namely humans, water, air, soil, plants, animals, and other natural resources. Aside from this, in Islam there are the concepts of Hablum Minallah and Hablum Minannas which posit that humans must have good vertical relations (humans with god) and good horizontal relations (humans with humans and nature). Thus, the environment is part of the teachings that are emphasized in Islam (Kamla, Gallhofer, \& Haslam, 2006). Helfaya et al., (2018) consider that Islamic social and environmental concern are motivated by the goals of duniya (temporal world) and akhira (afterlife).

According to these concepts, social concern is an integral part of sharia law. That is to say, Islamic banks which have special characteristics, namely making sharia the basis for their operations, must include social concern activities in their operations (Hassan, Abul; Latiff, 2009). The concern of Islamic banks is demonstrated by good social performance. Islamic banks' social performance can be demonstrated by their ISR disclosure (Farook, Hassan, \& Lanis, 2011; Mallin et al., 2014; Rahman \& Bukair, 2013), qardh financing (Falikhatun et al., 2016), zakah 
performance, and qardh al-hassan performance (Mukhibad, Kiswanto, \& Jayanto, 2017).

Mukhibad (2018), using Islamic banks in Indonesia as a research sample, demonstrates that ISR disclosure has a positive influence on profitability in the subsequent year. The results of the study by Mukhibad (2018) corroborate the findings of Platonova et al., (2016) who examine Islamic banks in Gulf Cooperation Council (GCC) countries and Mallin et al., (2014) who use 90 Islamic banks in 13 countries around the world and find that CSR disclosure has a positive influence on the profitability of the subsequent year. Siregar \& Bachtiar (2010) also find that CSR disclosure positively affects profitability.

Unlike previous research, social performance in this study uses financial ratios that can be used throughout the year. Expenditures in the course of the year can provide the benefits of increasing profitability in the same year. In ISR and CSR disclosures, companies are only able to carry these out at the end of the year when publishing annual reports, so, logically, the benefits for profitability can only be felt in the subsequent year. In this study, measurement of profitability is carried out in the same year, not in the subsequent year.

Janamrung \& Issarawornrawanich (2015), in their research in Thailand, find that corporate investment given in the form of CSR has an impact on increasing ROA. The results of this research are also corroborated by the research of Kanwal, Khanam, Nasreen, \& Hameed (2013) who find that there is a link between CSR and financial performance. Bahjat, Sabri, Mohammad, \& Sweis (2016) find that the amount of donations issued by companies can increase profitability as measured by ROA and ROE. However, Fadma El \& Boutti (2012) find that the CSR disclosure index does not affect ROA and ROE.

H1: The social performance (qardh al-hassan financing ratio, expenditure on zakah funds and qardh al-hassan funds) has a positive influence on profitability (ROA, ROE and NPM).

Social costs incurred by banks have the potential to be an effort to attract customers and prospective customers to use bank services, both directly and indirectly. For customers, CSR activities can strengthen their loyalty to companies (Arli \& Tjiptono, 2014; Gürlek, Düzgün, \& Meydan Uygur, 2017). In addition, Lee, Chang, \& Lee (2017) show that CSR can be used by a company to shape its brand image which is used as a marketing tool to support the company's business continuity.

In this study, customer satisfaction is measured by the amount of third party funds collected by banks in the form of deposits savings and current accounts. The reason for this increase in third party funds collected by banks is shown in the higher customer trust in the bank. The research of Pérez \& Bosque (2015) finds that CSR issued by banks will influence the image of banks, satisfaction, recommendations, and interest in repurchase behavior on the part of bank customers. Aramburu \& Pescador (2017) and Chung, Yu, Choi, \& Shin (2015) add that CSR issued by banks has a positive impact on increasing customer satisfaction and loyalty. More specifically, Sindhu \& Arif, (2017) find that zakah issued by Islamic banks can improve the reputation of the bank and subsequently have a positive impact on performance. In this study, satisfaction and interest in returning to using bank services is measured by debt ratios and the ratio of third party funds collected by banks.

$\mathrm{H} 2$ : The social performance (qardh al-hassan financing ratio, expenditure on zakah funds and qardh al-hassan funds) has a positive influence on debt.

H3: The social performance (qardh al-hassan financing ratio, expenditure on zakah funds and qardh al-hassan funds) has a positive influence on third party funds.

Increased loyalty due to social expenditure has the potential to increase the loyalty of customers who are beneficiaries of funds channeled by banks. The findings of Pérez \& Bosque (2015) demonstrate empirically that CSR is able to increase customer interest in using more products provided by the bank. The improved brand image of Islamic banks caused by an increase in the bank's social performance is able to increase customer interest in applying for loans or transfers of credit from conventional banks to Islamic banks. Another measure of customer satisfaction is the amount of financing channeled by banks. The assumption is that, if the finance channeled is large, then the satisfaction of the customer is high and vice versa; if the finance channeled is low then customer satisfaction is low.

H4: The social performance (qardh al-hassan financing ratio, expenditure on zakah funds and qardh al-hassan funds) has a positive influence on financing channeled by banks.

\section{Method}

The sample in this study comprises Islamic commercial banks in Indonesia with a period of observation from 2009 to 2017. Determination of the sample uses the purposive sampling method. The criteria for the sample selection are the issuing of certain reports, namely financial and Good Corporate Governance reports and presentation of zakah funds 
and qardh al-hassan funds channeled by the bank during the observation period. The variables used are measured by the following methods: (1) qardh al-hassan financing is measured by its ratio to all financing; (2) the expenditure of zakah funds is measured by the amount of zakah funds distributed by Islamic banks; (3) qardh al-hassan funds are measured by the amount of qardh al-hassan funds that has been distributed by banks; (4) Return on Assets (ROA) is measured by the ratio of net income to assets, (5) Return on Equity (ROE) is measured by the ratio of net income to equity; (6) Net Profit Margin (NPM) is measured by the ratio of the cost of profit sharing to the income from financing; (7) Third Party Funds are measured by the ratio of third party funds to assets; and (8) the amount of financing is measured by the ratio of financing to assets.

The data analysis uses the Structural Equation Model using the WarpPLS analysis tool. Test the validity of the model to use APC, ARS, AARS, AVIF and VIF score.

\section{Results}

The results of the descriptive analysis show that the distribution of zakah has a very large standard deviation. The magnitude of this standard deviation shows that the variety of Islamic banks in distributing zakah is very heterogeneous. Islamic banks in Indonesia, namely Bank Syariah Mandiri, distributed zakah amounting to IDR $50,794,078,580$ in 2014, while, in other banks, the distribution of zakah funds was IDR 392,800.

A circumstance similar to the distribution of zakah is the distribution of qardh al-hassan funds. The largest amount of qardh al-hassan funds distributed was carried out by BSM which was IDR 36,990,032,769 in 2016. The lowest amount of qardh al-hassan funds was IDR 2,000,000 which were channeled by Bank Jabar Banten in 2015. The large difference in distribution was due to the main source of qardh al-hassan funding being fines. Other sources of qardh al-hassan funds, such as infaq/shodaqah and waqf funds, have not been effectively utilized by banks. Similar to the distribution of zakah and qardh al-hassan funds, qardh financing also shows a high level of standard deviation.

Table 1. Description of variables

\begin{tabular}{lllll}
\hline Variables & Maximum & Minimum & Mean & St. dev. \\
\hline Zakah & $2.52049 \mathrm{E}+12$ & 392.800 & $1.78322 \mathrm{E}+11$ & $6.37141 \mathrm{E}+11$ \\
\hline QH & $3.7 \mathrm{E}+10$ & 2.000 .000 & $2.17 \mathrm{E}+09$ & $5.47 \mathrm{E}+09$ \\
\hline Qardh & $6.53 \mathrm{E}+12$ & 26.566 .666 & $9.2 \mathrm{E}+11$ & $1.44 \mathrm{E}+12$ \\
\hline ROA & 0.022646 & -0.03869 & 0.007357 & 0.007897 \\
\hline ROE & 0.297933 & -3.60468 & 0.022287 & 0.484553 \\
\hline NPM & 1.12258 & 0.002373 & 0.453487 & 0.172728 \\
\hline Third Party Funds & $7.79 \mathrm{E}+13$ & $5.08 \mathrm{E}+09$ & $1.87 \mathrm{E}+13$ & $2.03 \mathrm{E}+13$ \\
\hline Accounts Receivable & $1.95 \mathrm{E}+14$ & $9.08 \mathrm{E}+11$ & $2 \mathrm{E}+13$ & $2.84 \mathrm{E}+13$ \\
\hline Loans & $1.35 \mathrm{E}+13$ & $1.9 \mathrm{E}+11$ & $3.98 \mathrm{E}+12$ & $3.71 \mathrm{E}+12$ \\
\hline
\end{tabular}

The results of hypothesis testing with the Structural Equation Modeling (SEM) can be summarized and presented in the following figure and table: 


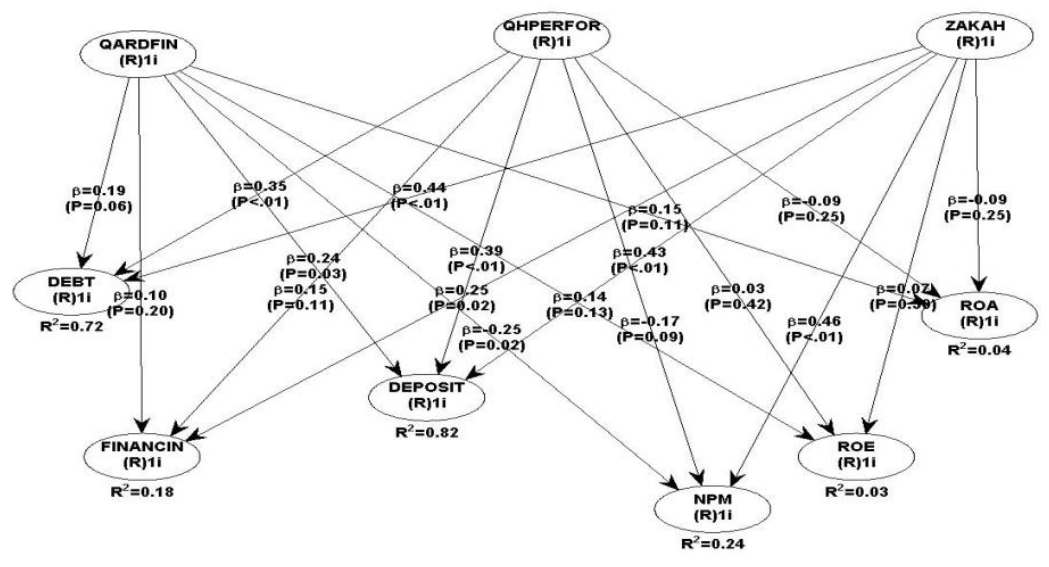

Figure 1. Results of model testing

Based on Figure 1, the results are summarized in the following table:

Table 2. Results of hypothesis testing

\begin{tabular}{|c|c|c|c|c|c|c|c|c|c|c|c|c|}
\hline \multirow{2}{*}{$\begin{array}{l}\text { Independ. } \\
\text { Var. }\end{array}$} & \multicolumn{2}{|c|}{ Debt Ratio } & \multicolumn{2}{|c|}{$\begin{array}{l}\text { Financing } \\
\text { Ratio }\end{array}$} & \multicolumn{2}{|c|}{$\begin{array}{l}\text { Third-Party } \\
\text { Funds }\end{array}$} & \multicolumn{2}{|c|}{$\begin{array}{l}\text { Net } \quad \text { Profit } \\
\text { Margin (NPM) }\end{array}$} & \multicolumn{2}{|c|}{$\begin{array}{l}\text { Return On } \\
\text { Equity (ROE) }\end{array}$} & \multicolumn{2}{|c|}{$\begin{array}{l}\text { Retun On Asset } \\
\text { (ROA) }\end{array}$} \\
\hline & B & Sign. & B & Sign. & B & Sign. & B & Sign. & $\beta$ & Sign. & $\beta$ & Sign. \\
\hline $\begin{array}{l}\text { Qardh } \\
\text { Financing }\end{array}$ & 0.195 & $\begin{array}{l}0.057 \\
* *\end{array}$ & 0.104 & 0.205 & 0.238 & $\begin{array}{l}0.026^{*} \\
*\end{array}$ & -0.253 & $\begin{array}{l}0.019 \\
*\end{array}$ & 0.143 & 0.127 & 0.152 & 0.111 \\
\hline $\begin{array}{l}\text { Qardh } \\
\text { al-hassan }\end{array}$ & 0.349 & $\begin{array}{l}0.002 \\
* * *\end{array}$ & 0.152 & 0.112 & 0.395 & $\begin{array}{l}<0.001 \\
* * *\end{array}$ & -0.168 & 0.088 & 0.026 & 0.422 & -0.087 & 0.245 \\
\hline Zakah & 0.444 & $\begin{array}{l}<0.00 \\
1 * * *\end{array}$ & 0.248 & $\begin{array}{l}0.021 \\
*\end{array}$ & 0.428 & $\begin{array}{l}<0.001 \\
* * *\end{array}$ & 0.463 & $\begin{array}{l}<0.00 \\
1 * * *\end{array}$ & 0.026 & 0.299 & -0.087 & 0.248 \\
\hline $\mathrm{R}^{2}$ & 0.72 & & 0.18 & & 0.82 & & 0.24 & & 0.03 & & 0.03 & \\
\hline
\end{tabular}

*** Sig. at $1 \%$; * Sig. at $5 \%$; sig. at $10 \%$

\section{Discussion}

The results show that bank expenditures on social activities, in the form of distribution of both zakah funds and qardh financing, has a positive impact on the debt received by banks. That is to say, there is the potential for social funds to increase investor confidence in providing debt to Islamic banks. Zakah is a social fund collected from employees' professional zakah, customers' zakah and the company's zakah which is distributed to parties entitled to receive zakah or, as they often referred to, the eight asnaf. The eight parties who are entitled to receive zakah are the destitute, poor, muallaf (converts), fi sabilillah (religious community activists), people who are heavily in debt, slaves, musyafir (stranded travelers), and amil (appointed collectors).

These findings demonstrate empirically that improving social performance will have an impact on the increasing debt received by banks. Companies with high CSR will have higher profitability, growth, and sales than companies with low CSR (Lins, Servaes, \& Tamayo, 2017). In addition, companies that have high CSR will increase debts (Lins et al., 2017). Thus, investor confidence can be built with good social performance (Kim, 2011; Lins et al., 2017).

Another consequence of channeling social funds is a positive impact on customer trust. This increase in customer trust in banks is characterized by empirical evidence showing that social expenditure (spending on zakah funds, qardh al-hassan and qardh financing) has a positive impact on the amount of third party funds received by banks, in the form of current accounts, savings acounts and time deposits. This condition indicates that the higher the bank's social performance, the more reliable the bank's performance as a safe place to save funds as well as make 
investments. The results of this study corroborate the findings of Aramburu \& Pescador (2017), Chung, Yu, Choi, \& Shin (2015), Kim (2011) along with Sindhu \& Arif (2017). Companies that have a lot of CSR activities tend to offer satisfaction, relationship value, relationship commitment, dependence, cooperation, and good communication between companies and consumers, employees, and investors (Kim, 2011).

Social expenditures can also improve a bank's image and attract its investors to increase their investment but it does not have a positive impact on increasing bank profitability. Logically, an increase in funds collected from investors constitutes an additional resource that can be used by banks to obtain profits. But the results of this study demonstrate empirically that the expenditure of social funds does not affect the amount of ROA and ROE of the bank. Here, there is a possibility that an increase in investor confidence is not accompanied by an increase in debtors, so the increase in funds collected by banks is not accompanied by an increase in the funding that is channeled. Moreover, the results of this study demonstrate that expenditure on social funds has no positive influence on the distribution of bank financing. Only the release of zakah can increase financing. This finding indicates that banks have the potential to experience difficulties in channeling or managing their loans. On the other hand, Islamic banks must pay the cost of raising funds in the form of margins, profit sharing, or ujroh (fees). As a result, ROA and ROE do not increase in line with the increase in the distribution of social funds.

These findings are different from the findings of Platonova et al., (2016); Mallin et al., (2014); Siregar \& Bachtiar (2010); and Mukhibad (2018) which show that bank social performance, as measured by ISR disclosure, has an impact on bank profitability. This difference between these and previous findings is due to how social performance is measured. In this study, social performance is measured by the amount of social expenditure, while the studies by Platonova et al., (2016); Mallin et al., (2014); Siregar \& Bachtiar (2010); and Mukhibad (2018) measures it by ISR disclosure. That is, it makes it possible for there to be a difference between social expenditure and bank ISR disclosure.

Another interesting finding is that qardh financing has a negative impact on Net Profit Margin (NPM). Qardh financing is a type of financing that is channeled by a bank but it does not provide profit sharing or revenue. However, with qardh financing, banks are only entitled to be the recipients of the return of the principal from the funds disbursed. The negative relationship between qardh financing and NPM shows that this type of financing is unfavorable for banks. Sa'ad \& Ibrahim (2015) explain that Qardh financing is a non-profit loan mechanism provided by banks to poor people to help them overcome certain financial difficulties or to grow small businesses for the welfare of their family. There is a possibility that the sources of this qardh financing are productive funds. On the other hand, banks must provide profit sharing for productive funds collected by banks. That is, the provision of qardh financing originating from productive funds will cause the ratio of income to profit sharing costs to be lower.

The results also show that the expenditure on zakah funds has an effect on increasing a bank's NPM. We suspect that the issuance of zakah can increase the confidence of investors and customers who own third party funds (see Sindhu $\&$ Arif, 2017). Trust in third party funds can remove the level of profit sharing from the things considered by customers before investing in Islamic banks. Increased third party funds are not followed by an increase in the amount of funding channeled. As a result, the income received by the bank is stagnant, and this causes the profit sharing with owners of third party funds to decrease.

According to Islamic concepts, the fulfilling obligations to all stakeholders is emphasized. The Islamic approach to stakeholders' perspectives can easily be seen in a company's relationships with key stakeholders (shareholders/owners and employees), and derivative stakeholders (suppliers, buyers/customers, debtors, competitors, and the natural environment) (Beekun \& Badawi, 2005). The results of this study, which show that the absence of a relationship between social performance and ROA and ROE, give rise to a provisional conclusion that the distribution of social funds has no purpose with regard to obtaining profits. Social performance by channeling social funds (zakah and qardh al-hassan) and distribution of qardh financing are part of fulfilling Islamic banks obligations towards stakeholders.

\section{Acknowledgements}

The authors would like to thank Economics Faculty, Universitas Negeri Semarang, Indonesia for supporting this research funding.

\section{References}

Ahmed, H., \& Tariqullah, K. (2007). Risk Management in Islamic Banking (chapter 10) in Handbook of Islamic Banking. In M. K. M. K. L. Hassan (Ed.), Handbook of Islamic Banking (p. 144). Northampton: Edward Elgar Publishing, Inc. https://doi.org/10.4337/9781847205414 
Aramburu, I. A., \& Pescador, I. G. (2017). The Effects of Corporate Social Responsibility on Customer Loyalty: The Mediating Effect of Reputation in Cooperative Banks Versus Commercial Banks in the Basque Country. Journal Business Ethics. https://doi.org/10.1007/s10551-017-3438-1

Arli, D., \& Tjiptono, F. (2014). Does Corporate Social Responsibility Matter To Consumers In Indonesia?. Social Responsibility Journal, 10(3), 537-549. https://doi.org/10.1108/SRJ-01-2013-0007

Asriati, R., Ulfah, P., \& Setyorini, C. T. (2016). Analisis Perbandingan Komponen Islamic Social Reporting (ISR) Pada Bank Syariah Antara Negara Indonesia dan Malaysia. In Simposium Nasional Akuntansi XIX (pp. 1-24).

Assegaf, Y. U., Falikhatun, \& Wahyuni, S. (2012). Bank Syariah Di Indonesia: Corporate Governance Dan Pengungkapan Pertanggungjawaban Sosial Islami (Islamic Social Responsibility Disclosure). In Proceedings of Conference In Business, Accounting and Management (CBAM) (pp. 255-267).

Bahjat, T., Sabri, H., Mohammad, K., \& Sweis, H. (2016). Effect of Corporate Social Responsibility on Profitability of Banks Working in Palestine ( Case Study 2013-2014 ). International Journal of Business Administration, 7(6), 107-114. https://doi.org/10.5430/ijba.v7n6p107

Beekun, R. I., \& Badawi, J. A. (2005). Balancing Ethical Responsibility Among Multiple Organizational Stakeholders: The Islamic Perspective. Journal of Business Ethics, 60(2), 131-145. https://doi.org/10.1007/s10551-004-8204-5

Boumediene, A. (2010). Is Credit Risk Really Higher in Islamic Banks?. Ssrn, (August), 1-36. https://doi.org/10.2139/ssrn.1689885

Chung, K., Yu, J., Choi, M., \& Shin, J. (2015). The Effects of CSR on Customer Satisfaction and Loyalty in China : The Moderating Role of Corporate Image. Journal of Economics, Business and Management, 3(5), 542-547. https://doi.org/10.7763/JOEBM.2015.V3.243

Dien, M. I. (1997). Islam and the Environment: theory and practice. Journal of Beliefs \& Values, 18(1), 47-57. https://doi.org/10.1080/1361767970180106

Fadma El, F., \& Boutti, R. (2012). Relationship between Corporate Social Responsibility and Financial Performance in Islamic Banking. Research Journal of Finance and Accounting, 3(10), 93-103.

Falikhatun, Assegaff, Y. U., \& Hasim. (2016). Menelisik Makna Pembiayaan Qardhul Hasan dan Implementasinya Pada Bank Syariah di Indonesia. Jurnal Keuangan Dan Perbankan, 20(1), 94-103.

Farook, S., Hassan, M. K., \& Lanis, R. (2011). Determinants of Corporate Social Responsibility Disclosure: the Case of Islamic Banks. Journal of Islamic Accounting and Business Research, 2(2), 114-141. https://doi.org/10.1108/17590811111170539

Fitrijanti, T., \& Alamanda, A. R. (2013). Analysis Of Disclosure Of GCG In Sharia Banking, Zakah , Social Performance, And Financing Risk - Study On Sharia Banking In Indonesia. In International Proceedings of Economics Development and Research (pp. 146-148). https://doi.org/10.7763/IPEDR.

Francis, B., Harper, P., \& Kumar, S. (2016). The Effects of Institutional Corporate Social Responsibility on Bank Loans. Business \& Society, 1-33. https://doi.org/10.1177/0007650316647952

Gürlek, M., Düzgün, E., \& Meydan Uygur, S. (2017). How Does Corporate Social Responsibility Create Customer Loyalty? The Role Of Corporate Image. Social Responsibility Journal, 13(3), 409-427. https://doi.org/10.1108/SRJ-10-2016-0177

Hameed, S., Wirman, A., Alrazi, B., Nazli, M., \& Pramono, S. (2004). Alternative Disclosure \& Performance Measures For Islamic Banks. In Second Conference on Administrative Sciences: Meeting the Challenges of the Globalization Age (pp. 1-37). Dhahran, Saudi Arabia: King Fahd University of Petroleum \& Minerals, Dhahran, Saudi Arabia.

Hamidi, M. L. (2016, October 31). Bank Syariah, Asosial?. Republika.Co.Id, p. 1.

Hassan, A., \& Latiff, H. S. B. A. L. (2009). Corporate Social Responsibility of Islamic Financial Institutions and Businesses. Humanomics, 25(3), 177-188. https://doi.org/10.1108/08288660910986900

Helfaya, A., Kotb, A., \& Hanafi, R. (2018). Qur'anic Ethics for Environmental Responsibility: Implications for Business Practice. Journal of Business Ethics, 150(4), 1105-1128. https://doi.org/10.1007/s10551-016-3195-6

How, J. C. Y., Karim, M. A., \& Verhoeven, P. (2005). Islamic financing and bank risks: The case of Malaysia. Thunderbird International Business Review, 47(1), 75-94. https://doi.org/10.1002/tie.20041 
Hull, C. E., \& Rothenberg, S. (2017). Difference of general- graphs and its corresponding matrices. Strategic Management Journal, 29, 781-789. https://doi.org/10.1002/smj

Janamrung, B., \& Issarawornrawanich, P. (2015). The Association Between Corporate Social Responsibility Index And Performance Of Firms In Industrial Products And Resources Industries: Empirical Evidence From Thailand. Social Responsibility Journal, 11(4), 893-903. https://doi.org/10.1108/SRJ-11-2013-0141

Jusoh, W. N. H. W., Ibrahim, U., \& Napiah, M. D. M. (2015). An Islamic Perspective on Corporate Social Responsibility of Islamic Banks. Mediterranean Journal of Social Sciences, 6(2), 308-315. https://doi.org/10.5901/mjss.2015.v6n2s1p308

Kamla, R., Gallhofer, S., \& Haslam, J. (2006). Islam, nature and accounting: Islamic principles and the notion of accounting for the environment. Accounting Forum, 30, 245-265. https://doi.org/10.1016/j.accfor.2006.05.003

Kanwal, M., Khanam, F., Nasreen, S., \& Hameed, S. (2013). Impact of Corporate Social Responsibility on the Firm's Financial Performance. IOSR Journal of Business and Management, 14(5), 67-74.

Kim, J.-K. (2011). Effects of Corporate Social Responsibility on BtoB Relational Performance. International Journal of Business and Management, 6(2), 24-34. https://doi.org/10.1057/bm.2010.54

Lassoued, M. (2018). Comparative study on credit risk in Islamic banking institutions: The case of Malaysia. Quarterly Review of Economics and Finance. https://doi.org/10.1016/j.qref.2018.05.009

Lee, C.-Y., Chang, W.-C., \& Lee, H.-C. (2017). An Investigation Of The Effects Of Corporate Social Responsibility On Corporate Reputation And Customer Loyalty - Evidence From The Taiwan Non-Life Insurance Industry. Social Responsibility Journal, 13(2), 355-369. https://doi.org/10.1108/SRJ-01-2016-0006

Lev, B., Petrovits, C., \& Radhakrishnan, S. (2012). Is doing good good for you? Yes , charitable contributions enhance revenue growth. Strategic Management Journal, 31(2), 182-200. https://doi.org/10.1002/smj

Lins, K. V., Servaes, H., \& Tamayo, A. (2017). Social Capital, Trust, and Firm Performance: The Value of Corporate Social Responsibility during the Financial Crisis. Journal of Finance, 72(4), 1785-1824. https://doi.org/10.1111/jofi.12505

Mallin, C., Farag, H., \& Ow-yong, K. (2013, March). Corporate social responsibility and financial performance in Islamic banks. Journal of Economics Behavior \& Organization, 103, s21-s38. https://doi.org/http://dx.doi.org/10.1016/j.jebo.2014.03.001

Mukhibad, H. (2018). Peran Dewan Pengawas Syariah dalam Pengungkapan Islamic Social Reporting, pp. 299-311.

Mukhibad, H., Kiswanto, \& Jayanto, P. Y. (2017). An Analysis on Financial and Social Performance of Islamic Banks in Indonesia. International Journal of Monetary, Economic Finance, 10(3/4), 295-308.

Mukhibad, H., Nurkhin, A., \& Khafid, M. (2016). Have Indonesia Islamic Bank Met Tawazun Principle? An Analysis of Financial and Social Performance. In 4th ASEAN International Conference on Islamic Finance "A Re-evaluation and Way Forward” (p. 1). Malaka: IIUM Institute of Islamic Banking and Finance.

Pérez, A., \& Bosque, I. R. del. (2015). Corporate Social Responsibility and Customer Loyalty: Exploring The Role of Identification, Satisfaction and Type of Company. Journal of Services Marketing, 29(1), 15-25. https://doi.org/10.1108/JSM-10-2013-0272

Platonova, E., Asutay, M., Dixon, R., \& Mohammad, S. (2016, July). The Impact of Corporate Social Responsibility Disclosure on Financial Performance : Evidence From GCG Islamic Banking Sector. Journal of Business Ethics, 44, 1-12. https://doi.org/10.1007/s10551-016-3229-0

Pratama, A. N. A. (2018). Determinan Pengungkapan Islamic Social Reporting (ISR) Pada Perbankan Syariah Dengan Komisaris Independen Sebagai Variabel Moderating. Al-Mashrafiyah - Jurnla Ekonomi, Keungan Dan Perbankan Syariah, 1(2), 103-115.

Rahman, A. A., \& Bukair, A. A. (2013). The Influence of the Shariah Supervision Board on Corporate Social Responsibility Disclosure by Islamic Banks of Gulf Co-Operation Council Countries. Asian Journal of Business and Accounting, 6(2), 65-104.

Rizk, R. (2014). Islamic environmental ethics. Journal of Islamic Accounting and Business Research, 5(2), 194-204. https://doi.org/10.1108/JIABR-09-2012-0060

Sa'ad, A. A., \& Ibrahim, U. B. (2015). Social justice and charitable-trust in islamic financial transactions. International Journal of Business, Economics and Law, 8(1), 1-4. 
Santoso, A. L., \& Dhiyaul-haq, Z. M. (2017). Determinan Pengungkapan Islamic Social Reporting pada Bank Umum Syariah di Indonesia. Jurnal Dinamika Akuntansi Dan Bisnis, 4(2), 125-142.

Sari, D. D. (2018). Pengungkapan Islamic Social Reporting Pada Bank Syariah Di Indonesia Dan Malaysia Tahun 2014-2016. Institut Agama Islam Negeri Surakarta.

Servaes, H., \& Tamayo, A. (2013). The Impact of Corporate Social Responsibility on Firm Value: The Role of Customer Awareness. Management Science, 59(5), 1045-1061. https://doi.org/10.1287/mnsc.1120.1630

Sindhu, M. I., \& Arif, M. (2017). Corporate Social Responsibility and Loyalty: Intervening influence of Customer Satisfaction and Trust. Cogent Business \& Management.

Siregar, S. V., \& Bachtiar, Y. (2010). Corporate social reporting : empirical evidence from Indonesia Stock Exchange. International Journal of Islamic and Middle Eastern Finance and Management, 3(3), 241-252. https://doi.org/10.1108/17538391011072435

Sofyani, H., Ulum, I., Syam, D., \& Wahjuni, S. (2012). Islamic Social Reporting Index Sebagai Model Pengukuran Kinerja Sosial Perbankan Syariah (Studi Komparasi Indonesia dan Malaysia). Jurnal Dinamika Akuntansi, 4(1), 36-46.

Sugianto, \& Harapan, N. (2017). The Integration of Disclosure of Islamic Social Reporting (ISR) In Islamic Bank Financial Statements. In SHS Web of Conferences 36 (Vol. 11, pp. 1-14). https://doi.org/10.1051/shsconf/20173600011 